\title{
Markets, Social Embeddedness and Precapitalist Societies: the Case of Village Tradestores in Papua New Guinea
}

\author{
George Curry \\ School of Social Sciences and Asian Languages \\ Curtin University of Technology \\ GPO Box U1987 \\ Perth \\ WA 6845 \\ Australia \\ e-mail: curryg@spectrum.curtin.edu.au
}

\begin{abstract}
The village tradestore in rural Papua New Guinea is a physical expression of modernity in the heart of the village and is symbolic of the new economic and social formations associated with incorporation. This paper examines how the village tradestore is positioned in relation to these processes of change by considering the management and operation of several tradestores in the Wosera sub-district, East Sepik Province. The paper reports on the ways in which values, relationships and behaviours associated with both the introduced market economy and the precapitalist socio-economy become articulated through the ostensibly modern phenomenon of tradestores.
\end{abstract}

Key words: new economic geography, rural development, small business development, transitional societies, Melanesia, Pacific Islands.

\section{Introduction}

The social dimension of economics is receiving increasing attention in the disciplines of economic sociology, economics and economic geography with the realisation that economic, social and cultural relations are inevitably entangled. The rise in the social can be traced from Karl Polanyi's (1957) work on the social nature of markets to Mark Granovetter's (1985) notion of the embeddedness of economic transactions in ongoing social relations. These ideas have been embraced enthusiastically by a growing band of geographers working on modern economies, with the result that the parameters of a new economic geography are being mapped (for an overview see Thrift and Olds, 1996).

In this paper I wish to show how the concept of social embeddedness can also usefully be applied to the study of so-called "transitional" societies in the developing world where market economies are emerging. While the social and cultural embeddedness of precapitalist societies has long been recognised, it is often assumed that as societies move from a largely subsistence, precapitalist base towards a market economy, social relations are progressively commoditised as the economic becomes disembedded from the social and cultural. I argue that this is not necessarily the case as the emergent elements of a market economy in transitional societies remain very 
much entangled with the social and cultural, to the extent that the economic can become subordinated to the social and cultural.

I address these issues through an examination of the operations of several village tradestores in the Wosera sub-district, East Sepik Province, Papua New Guinea (PNG) (Figure 1). The village tradestore is ubiquitous in Melanesia, and is for many rural people their first and most frequent point of contact with the new economic and social formations associated with the introduced market economy. Tradestores are present even in the most isolated and remote communities and were one of the earliest manifestations of incorporation, preceded only by labour migration and perhaps cash cropping. Therefore it is of interest to examine how the village tradestore is positioned in relation to the process of transformation. For instance, to what degree do their management and operation reflect relationships, values and behaviours associated with the introduced market economy? Or, conversely, how are their operations and roles in village socio-economies shaped by values and norms identifiable with the precapitalist economy? And, how do the two forms of socioeconomy become articulated through the ostensibly "modern" phenomenon of tradestores? In answering these questions, the paper seeks to forge stronger theoretical linkages between the new (socially embedded) economic geography and recent work on socio-economic change in the developing world.

I begin with a brief overview of the social embeddedness literature of the new economic geography and link this to current work on socio-economic change and the articulation of market and non-market socio-economic forms in PNG. A short description of the study site follows together with an outline of the main characteristics of village tradestores including aspects of their daily operations. Next, spatial patterns of tradestore expenditure are analysed to determine the role of distance and kinship on store patronage. Three case studies of tradestores follow to illustrate processes of capital formation and profit distribution to reveal the extent to which tradestores represent the commercialisation of social relationships and to identify the underlying principles guiding their operations. While most research in the new economic geography has been confined to modern economies, I argue that these ideas are particularly relevant for the analysis of emerging market phenomena in transitional societies like PNG where precapitalist socio-economic relations and values remain an enduring influence.

\section{Background}

The new economic geography is now revealing the social and cultural influences on economic success, even in the international financial centres of western capitalism (Amin and Thrift, 1992; Thrift, 1994; 1996; Leyshon, 1997). Increasingly, research is highlighting the importance of social networks of personal contact for the transmission of business information and knowledge (e.g., Amin and Thrift, 1995; Yeung, 1994), and for the generation of trust in economic relationships (e.g., Zucker, 1986; Platteau, 1994a; 1994b; Misztal, 1996; Leyshon et al., 1998). The notion of the market as an impersonal neutral arena for pure commodity exchange is therefore being challenged (Swedberg, 1994), with the realisation that the social nature of markets involves 'complex moral and institutional orders regulating not only the 
conduct of exchange but also what is defined as exchange in the first place' (Thrift and Olds, 1996: 315). Even the notion of commodity exchange as a defining characteristic of western market economies has been questioned by some who see that a great deal of what passes as commodity exchange bears close resemblance to gift exchange (e.g., Carrier, 1995; 1997). While commodity exchange is about profit and consumption and presumes independence between the parties to a transaction, gift exchange is about the creation and maintenance of personal relationships (Gregory, 1982). Gift exchange is, therefore, explicitly social in the sense of forming identities and interpersonal and group relationships, which in turn are implicated in economic success. All these studies show how economic transactions are firmly grounded in ongoing social relationships.

One focus of this recent work in geography is ethnic business practices, particularly among the overseas Chinese, and highlights the role of social networks for raising capital, transmitting information and generating trust in economic relationships (for a review see Light and Karageorgis, 1994). These social networks can be based on kinship, regional and sub-ethnic ties including common language, and ties formed through a shared educational history or common business and social contacts (Thrift and Olds, 1996: 324). Also, gift exchange is an important element in these networks for building trusting interpersonal relations in economic activities (Smart and Smart, 1991; Hsing, 1996), and such exchange is often grounded in shared cultural understandings of the meaning of gift exchange. Thus, as Hsing (1996) notes, Taiwanese business entrepreneurs have less difficulty in making capital investments in southern China because their local business partners share with them a common cultural heritage, language and understanding of the cultural meanings, values and obligations associated with gift exchange.

Much of this current work in the new economic geography on the social embeddedness of economies has been concerned with modern economies. However, as indicated in the introduction to this paper, these ideas are also relevant to transitional societies in the developing world. In making this point it is important to recognise that geographers and anthropologists working in the developing world have long recognised the social and cultural context of economies and economic change (e.g., Brookfield, 1973; Finney, 1973; Howlett, 1973), and work in this tradition continues (e.g., Simon, 1997; 1998; Nederveen Pieterse, 1994). ${ }^{1}$ For example, PNG bigmen $^{2}$ were quick to seize opportunities afforded by the cash economy (Finney, 1973; Feil, 1987), and Finney (1973) asserted that Gorokan society in the Eastern Highlands, PNG was 'pre-adapted' to an introduced capitalist economy.

Entrepreneurs (motivated by traditional desires for wealth and prestige), are either bigmen, or men who use the techniques of bigmen to achieve their objectives: these new entrepreneurs gain prominence by appealing to their supporters 'in indigenous rather than foreign idioms' (Strathern, 1974).

More recently, research in PNG is challenging determinstic notions of the nature of change with the recognition that the direction of change is uncertain and dynamic, and indigenous socio-economic and cultural values remain an enduring influence.

Gregory's (1980; 1982; also 1997) use of the distinction between between gift and commodity exchange provides a conceptual framework for analysis of partly transformed societies. ${ }^{3}$ The fact that the exchange objects (gifts and commodities) of 
two seemingly separate socio-economic frameworks can effect a crossover, whereby gifts become commodities and vice-versa raises several intriguing questions for geographers that have implications for how we view change in transitional societies. If an object can be a gift or a commodity 'depending on the social context of the transaction', then how do we analyse relations of production and exchange? Are we correct to interpret, for example, cash crop production, roadside markets and tradestores as "pure" phenomena of the market economy when profit accumulation and consumption may not be the primary motivating forces?

This ambiguity between the two socio-economic frameworks is exemplified by how cash has been incorporated into indigenous social and political systems in PNG societies $^{4}$ (e.g., Boyd, 1985; Maclean, 1989; Clark, 1989; Nihill, 1989). Cash has assumed a role as a gift item in indigenous exchange such as brideprices, affinal and mortuary exchanges. For instance, an income and expenditure survey of a Wosera village in 1989 revealed that nearly half of cash income was derived from the indigenous exchange economy (Curry, 1992). Other studies reach similar conclusions about the importance of cash in indigenous exchange. In the Okapa district, Eastern Highlands, for example, Boyd (1985) documented how traditional pig festivals have been transformed by the 'commercialisation of ritual', into "singsing bisnis", 5 where cash, beer and pork are transacted both as gifts and commodities. Profits are channelled into both capital investment and indigenous exchange such as brideprices. The demand for cash, therefore, is not confined to an urge to consume in the market economy nor solely by a desire to raise investment capital for market enterprises; it is also partly determined by the exigencies of indigenous exchange. Incorporation appears to be giving rise to a variety of economic and social forms that contain elements that are both "traditional" and "modern" in form and meaning (e.g., Gregory, 1982; Goddard, 1995; Curry and Koczberski, 1998).

But how far can this analysis be taken? While elements and values associated with the modern market economy can penetrate and shape indigenous socio-cultural and economic formations, to what extent is the reverse true for what are, ostensibly, manifestations of the market economy like village tradestores? Village tradestores are a useful phenomenon to examine because they are considered to be a forerunner of emergent rural capitalism in the midst of what are largely subsistence-based rural economies. Moreover, despite their ubiquity in rural Melanesia and their potential to provide insights into processes of change in societies where indigenous economic and social formations remain strong, they have, with a few exceptions (e.g., Finney, 1973; Grossman, 1986; Carrier, 1992) received surprisingly little attention in the literature on socio-economic change.

Carrier (1992; also Carrier and Carrier, 1989) describes two types of tradestore on Ponam Island, PNG which he defines as customary and business. The former were established as a service for fellow villagers, to provide goods and cash to invest in indigenous exchange, and to allow the operator to extend the period of consumption of these types of imported foods. These operators kept no records and when their stores became insolvent they simply wrote to kin working in towns requesting cash remittances to enable them to replenish their stock. The profit motive did not feature in their operations and other factors including indigenous exchange took precedence over market considerations. The second type of tradestore that Carrier identified was 
the business enterprises proper, where operators attempted to make profits and kept records of transactions. These operators strove to increase the stock of capital through time with the aim of expanding their stores or making other capital investments. Carrier notes that these business store operators were atypical because they were 'marginal' in the sense they were poorly integrated into Ponam society. Perhaps because their social and kinship networks were not well developed within Ponam society they were able to circumvent the demands of the indigenous exchange economy. One could argue that if they were more firmly embedded within indigenous networks of exchange rather than "outsiders", their stores would have functioned more as customary stores. ${ }^{6}$

As I argue below, Wosera tradestores share similarities with the range on Ponam Island, but rather than an individual store operating solely in either the realm of kastam or bisnis, ${ }^{5}$ Wosera stores bridge both realms simultaneously because they are constituted of elements from the introduced market economy and the pre-existing indigenous economy. The economic dimensions of their operations are, therefore, invariably entwined in social and cultural relations of identity. However, their embeddedness in social and cultural relations differs in some fundamental ways from the forms of embeddedness described above for modern economies where profits remain the ultimate objective and concern. In PNG, market imperatives can, and often do, become subordinated to the indigenous and premodern; economic relations are often non-market in form, and profits are not always a central, over-arching concern to which, for example, gift exchange is subordinated.

\section{PNG and the Wosera sub-district, East Sepik Province}

PNG has a total land area of 463,000 sq. $\mathrm{kms}$, is located in the eastern half of the island of New Guinea and includes some 600 islands. Much of the terrain is rugged and mountainous which restricts human settlement, the scope of agricultural production and the provision of transport and communications. The population of over four million is culturally and linguistically diverse, with more than 700 language groups present. Approximately $85 \%$ of the population live in rural areas and are largely self-sufficient in food production, and many derive cash income from export cash crops and local food markets. Until recently, export earnings have been based largely on agricultural production. In the last decade there has been a shift towards mineral and natural resource development (especially gold, petroleum, gas and timber), and mining is now the most important sector in the economy (Connell 1997: 165). Despite the considerable wealth generated by the mineral-led growth of the 1990s, economic development remains limited in most rural areas of PNG.

By Papua New Guinea standards, the Wosera are poor. In 1993 national per capita income was K520, and K320 for the East Sepik Province (1K = A \$1.51) (AusAID, 1995: 131, 149). Per capita income is even lower in the Wosera, and was K24 in Miko 2 Village in 1989. ${ }^{7}$ Villagers are heavily reliant on subsistence production which is characterised by a bush fallow system of gardening of yams (Dioscorea esculenta) and taro (Colocasia esculenta and Xanthosoma sagittifolium), alternating seasonally with sago processing. 
From the early 1930s, the Wosera have had a fairly strong engagement with the capitalist economy. During the 1930s there was some labour migration when Wosera men worked as indentured labourers on the coastal plantations or in the goldfields of Wau and Bulolo. After the war relations with the capitalist economy intensified through higher rates of labour migration (Curry and Koczberski, in press), and the introduction of export cash cropping, especially following the introduction of Robusta coffee in $1957 .^{8}$ Villagers also engage in the cash economy through cultivating garden crops for local roadside markets (e.g., peanuts, greens and tobacco), and raising pigs for sale.

The data presented in this paper are from the villages of Miko 1 and 2 located in the north-east of Wosera sub-district (Figure 1). Data on tradestore patronage were collected through weekly surveys of 31 households in Miko 2 Village over a 12 month period in 1988/89, while case studies of individual tradestores were collected in both villages. Miko 2 Village which is approximately half the size of Miko 1 Village had a resident population of 213 in 1989.

\section{Characteristics of Miko tradestores}

Village tradestores were first established in the sub-district in the late 1950s and early 1960 s, some with mission assistance. They spread rapidly and today most Wosera villages would have at least one operational tradestore. In 1985, there were 314 licensed tradestores serving a population of almost 20,000, or 1.61 tradestores per 100 persons (Heywood et al., 1986: 123-124).

Wosera tradestores are typically small in size and constructed of bush materials. Split palm is used for flooring and sago thatch for roofing. Some stores have a corrugated iron roof which gives the store a "modern" look and more prestige. They supply low order goods of mostly imported stock such as rice, tinned fish, kerosene, matches, newspaper (for rolling tobacco), lamp wicks, lighter flints, soap and batteries, but some stores sell as few as one or two types of goods. Tinned fish and rice are the most important items of stock and account for the largest proportion of sales (Figure 2; also Heywood et al., 1986). Generally, levels of stock are low and, unlike town stores, they are often closed for much of the day, opening in the early evening for a short period if customers arrive. Very few operate as full-time businesses and most proprietors remain engaged in subsistence production, export cash cropping and garden production for sale at local markets. Tradestores often survive on narrow profit margins (less than 7\% according to some estimates - Curry, 1992: 114; also Lea et al., 1988: 27) and can easily become insolvent. Many sales are on credit, sometimes making restocking a problem (see below).

Less common in the sub-district are the larger, more business-orientated stores where sufficient capital has been accumulated over the years to invest in permanent structures. These stores often have a concrete floor, walls of milled timber, and a corrugated iron roof. They have lower operating costs and generally carry a wider range of stock than the smaller stores. ${ }^{9}$ Stock is often bought in bulk at discounted prices from wholesalers in the provincial capital of Wewak, making them less vulnerable to insolvency than small tradestores. ${ }^{10}$ No such stores have yet been 
established in Miko 2 Village, though there are several in neighbouring villages. This paper examines the small to medium size tradestore which is the most common type of Wosera store.

\section{Tradestore expenditure and patronage}

Tradestores account for $67 \%$ of expenditure in the market economy and, as mentioned above, tinned fish and rice dominate sales. These items are more prestigious than locally produced foods and have been incorporated as gifts in indigenous exchange. ${ }^{11}$ Local roadside markets, despite offering a wider range of relatively less expensive foods, account for only $24 \%$ of expenditure. ${ }^{12}$ Although tradestores account for the largest proportion of expenditure, the amounts and frequency of purchases are low, and there is considerable variation between households (Table 1). Some households with low levels of tradestore expenditure compensate with increased purchases at local markets. However, a few households have extremely low expenditures in all areas of the market economy, indicating a much greater reliance on subsistence production for household survival.

With regard to the spatial distribution of tradestore expenditure, a relatively high proportion (46\%) of store purchases is made within the Wosera despite lower prices in town (Table 2; Figure 1). Town purchases tend to be incidental to journeys there for other reasons (e.g., visiting relatives in hospital, trips to market, court cases, post office etc.), unless villagers intend purchasing a larger than usual quantity of tinned fish or rice for an important ceremonial event such as a mortuary feast. Generally, most villagers buy from Wosera tradestores, and, when store purchases are made, expenditure increases and transaction frequency decreases with distance from the village (Table 2).

This broad spatial pattern of tradestore expenditure appears to conform with the market logic of gravity models of rational shopping behaviour (e.g., Berry, 1967; Williams, 1979). However, this macro-level pattern masks the role of the indigenous socio-economy in shaping patterns of tradestore expenditure at the local level. Grossman's (1986) survey of intra-village store patronage in Kapanara Village, Eastern Highlands Province, revealed that while distance between residence and store was important, villagers tended to patronise subclan tradestores. Such an analysis is not straightforward for the Wosera because hamlets tend to be agnatic clusters of close relatives and almost $25 \%$ of Miko households had a subclan tradestore within their hamlet. Despite this difficulty, kinship emerges as an important factor in tradestore patronage in Miko. While only $30 \%$ of household purchases are made at the nearest tradestore, $43 \%$ of purchases are made at the subclan store with which each household is affiliated (Table 3 ).

However, these data do not reflect the full significance of kinship in store patronage because, like Grossman's study, they consider agnatic relationships only. Grossman noted a high proportion of tradestore transactions by non-clan members in hamlets where residents' clan affiliations were highly mixed. But it is possible in mixed clan hamlets that non-clan residents are related affinally (by marriage). Indeed, for the Wosera, affinal relationships are economically, socially and culturally important, 
especially those between a man and his mother's and wife's natal lineages and the lineages into which his sisters and daughters marry. If both affinal and subclan affiliations are taken into account, then $67 \%$ of household tradestore purchases are made at stores operated by kin.

Again, this figure under-estimates the influence of kinship on store patronage for two reasons. First, some households were from immigrant lineages (lineages of four or less generations of village residence) and still retained ties with their natal subclans and other sets of relatives in their source villages. Because tradestores outside Miko were not identified individually when recording these data, then tradestore purchases where a relationship existed between buyer and store operator went mostly unrecorded. Secondly, some of these immigrant lineages tended to follow the purchasing patterns of their host lineages to whom they were related as wife-takers (WTs), a culturally prescribed unequal exchange relationship that permitted them ongoing access to the resources of their hosts (Curry, 1997). For example, two immigrant households followed the spending patterns of their host lineages with a substantial proportion of their purchases at a tradestore in a neighbouring village -- a tradestore whose operator was closely related to their host lineage, but not themselves. However, it appears that kinship, through the host lineage to which they were attached, influenced their spending patterns.

In summary, villagers' tradestore spending patterns conform with spatial models of shopping behaviour at the macro-scale, but at the local level kinship emerges as an important determinant of tradestore patronage. Thus, as "consumers" in the market economy, villagers' patterns of tradestore expenditure at the local level are, like Kapanara villagers, firmly grounded in social and cultural relations shaped by indigenous social organisation and kinship.

\section{Capital formation and profit distribution}

If we examine tradestore establishment, management and profit distribution, further evidence emerges of the key role of the indigenous socio-economy in shaping their operations. The three examples presented below were moderately "successful" in terms of turning a profit, but it is evident that while superficially appearing to be a phenomenon of the modern market economy, they are in functional and symbolic terms a hybrid socio-economic form and deeply embedded in social and cultural relations.

\section{Case 1 Puse's store}

Puse is known for his bisnis save, that is, a knowledge of the ways of the "modern" world and business generally. Over the years he has managed or invested in various business ventures and his previous store was moderately successful, but became insolvent when the store profits of K900 were invested in an unsuccessful transport business. ${ }^{13}$ In 1987 he founded a new tradestore after persuading various kin to contribute capital (Table 4). Most of the start-up capital together with the recycled corrugated iron for building the store were obtained from fictive mother's brothers. Banked profits were K1,600 after one year, but were reduced to K1,300 on the 
insistence of a share of the profits from Salpus, a senior member of Puse's subclan. In early 1988 Puse invested K700 of the banked profits in a passenger transport business with a relative living in the next village, an action that angered some tradestore partners. Using his seniority in the subclan, Salpus claimed the K700 belonged to him because he had made a relatively large initial investment in the store and had also ferried stock on his employer's truck from wholesalers in Wewak. Salpus walked away from the business and a serious rift developed between the two subclan members.

Puse continued to run the store, but several months later an armed gang robbed the store taking all stock and cash on the premises including some personal belongings of Puse. Following this incident Puse gave the remaining K600 of banked profits to his MBs for distribution amongst their lineage. One of the MBs reported that all K600 was passed initially to Joe because of the large initial investment by his family. Joe later gave K50 each to Bert and Jack. ${ }^{14}$ However, Puse was able to accumulate profits separately from the bank account. After the robbery he invested some money in a new tradestore in a neighbouring village managed by a fictive sister's son.

Following the robbery, rumours circulated that a local businessman was persuaded by Salpus to arrange the robbery. Puse was identified in court as the source of these rumours and was ordered to compensate the businessman with two large shell rings and some cash, an amount Puse claimed he could not afford. Shortly after the court case Puse fell ill and sorcery, performed using his personal belongings taken during the robbery, was identified as the cause. At considerable expense to Puse the sorcery was said to have been neutralised. With the impending compensation payout and the threat of further sorcery, Puse took refuge in West New Britain where he remained for five years. He returned home with sufficient capital to start another store, and when I visited in 1996 the corrugated iron from the old store was gone and he was building a new one from bush materials.

\section{Case 2 Bill's store}

Bill and members of his patrilineage constructed a tradestore from bush materials in 1979. Six members of his patrilineage and a MB contributed a total of K600 towards stocking the store, but he was unable or unwilling to recount how much cash he himself contributed. In 1982 the accumulated profits of K500 were expended on a replacement store of milled timber walls, corrugated iron roof and concrete floor. ${ }^{15}$ Thus the store successfully made the transition to a "modern" store in terms of its built structure, bringing status and prestige to Bill's lineage.

By 1985 profits had accumulated to K700. In the same year, however, Bill became very ill and remained in poor health until late 1988. During his illness the store went into decline and he began to use the accumulated profits of K700 in both the market and indigenous exchange economies in strategies to redress his health problems. In direct attempts at overcoming sorcery (the perceived cause of his illness), he channelled K300 in cash and K130 worth of shell rings through exchange networks to various men reputedly skilled in neutralisng sorcery. He also spent K50 on a young pig and K100 on tinned fish and rice to stage communal feasts for his clan group and other kin. These feasts were attempts to enlist the support of ancestral spirits in 
overcoming his illness. The remaining profits of K120 were expended on food and transport when he was hospitalised for a short period.

When I interviewed Bill in late 1989 the store was closed and he had fully recovered from his illness. He had no money to restock the store, but intended to raise more cash from relatives to re-open the store. He planned to rebuild the store gradually and was prepared to take his time. Bill was adamant that his store had been a success, a view shared by other members of his patrilineage who were present at the interview. Without the cash reserves provided by profits Bill was convinced he would not have survived the sorcery onslaught. As he said, and this point was made on several other occasions by Wosera villagers, 'one needs cash nowadays to survive in the Wosera without cash reserves one won't survive sorcery attacks.'

\section{Case 3 Patrick's store}

This store was started around 1975 by Patrick and his brother Nakravi and it ran successfully until 1985. There were at least eight cash investors (possibly up to a dozen) in the original store, most of whom were drawn from the patrilineage or subclan group. The single largest cash investor was Patrick's WB, Beno, who invested K400 of the total estimated cash investment of K650. Several people contributed labour rather than cash by helping to clear a site for the store and cutting bush materials for its construction. According to Patrick the store was wound up in 1985 because of increasing complaints from investors and demands for profits to be distributed.

When the store closed in 1985 undistributed profits amounted to K2,900. Villagers who had contributed labour for the store's construction each received K3 or K4. Those who had invested K10 each received K30 in return, but this rate of return was not consistent across all levels of initial investment nor kin type. For instance, one person who invested K20 received K30 in return. It seems likely that the small K10 investors were more distantly related subclan members and they received a standard rate of return, whereas the rate of return for larger investors, who were more closely related to the patrilineage, varied depending on kinship status and other factors including, for example, occasional assistance with the store. It is also noteworthy that the single largest investor, Beno, declined a profit share stating that it was his way of helping his affines, specifically his sister's sons. This form of assistance from a wifegiver, particularly the mother's brother, is quite common in PNG, and in the Wosera context involved notions of mother's brother in a nurturing and protective role of his sister's children so that they "grow up strong". It is in this same sense that Beno wanted their enterprises to grow and prosper. However, the stated returns to individual investors (including Patrick and Nakravi) totalled approximately K900 leaving about $\mathrm{K} 2,000$ unaccounted for. It is probable that the store operators held onto this amount, though they claimed to have received much lesser amounts.

When the store closed it segmented into three new tradestores formed around patrilineal members of the original store, in a way not dissimilar to the segmentation of lineages when they become too large. In many ways it would be incorrect to consider the original store a failure. It served a purpose in being a visible sign of the subclan's success. When the younger men who were original investors reached a 
stage in their lives where they desired to realise their own political ambitions through raising their status and prestige, the group segmented to form three new stores. It was a generational change in which a new generation of young men sought to make their mark in the village socio-economy by adopting the symbols and signs of success through creating networks of supporters to pool funds to establish their own stores in much the same way they were attempting to do so in other areas of their lives.

The three new stores started in 1986 each using as part of their start-up capital their profit share from the original tradestore. Two stores have attracted other investors, but the third was unwilling or unable to do so and is a sole operation. This store is smaller than the other two and carries a more limited range of stock. It was burgled in early 1988 when the owner was absent from the village, and, in 1989, the store was struggling to survive. The other two stores appear moderately successful, and both their operators intend expanding into other areas like transport businesses when sufficient profits have been accumulated.

\section{Discussion}

The three case studies presented above illustrate several points concerning the social and cultural embeddedness of business enterprises in partly transformed societies. These relate to the role of tradestore goods and profits as a reserve of wealth to be deployed in indigenous exchange as the need arises, their role in the formation of social identities and social capital, and how they represent symbolically success in both kastam and bisnis. I expand on each point below.

Tradestore stock is something that can be put to various uses: it can be sold (often on credit), consumed or invested in networks of indigenous exchange. Moreover, store foods such as tinned fish and rice are prestigious because of their association with the modern market economy and its industrial infrastructure. These foods are now an important supplement to locally produced foods such as yams and sago in certain contexts of exchange such as feasting ceremonies associated with mortuary rituals, dispute resolutions and the appeasement of ancestral spirits in cases of illness induced by these spirits. Store operators and their supporters certainly consume much of the profits themselves through direct consumption of stock. Store goods and cash profits also enable them to make strategic investments in indigenous exchange as well as providing them with a margin of security against sorcery. In Case 2, for instance, tradestore profits and stock served as a reserve against sorcery during Bill's illness, and many store operators and their co-investors see this as an important role for tradestores.

The life of a store and whether or not it prospers depends on several factors including the ability of the store operator to maintain control of the competing interests of store investors, often by deftly manipulating sentiments and values associated with the two forms of socio-economy. At one subclan meeting to discuss the imminent insolvency of their subclan store, key investors appealed to subclan members to repay their debts at the store in the interest of subclan solidarity and to maintain the subclan's reputation for bisnis. Subclan solidarity was expressed rhetorically as "brothers" helping "brothers" as with raising brideprices and compensation payments, and it was 
suggested that if the store were to become insolvent the subclan may become riven by divisions and discord -- conditions conducive to an outbreak of sorcery and ancestralinduced illnesses. Conflicts between co-investors were apparent in two of the case studies: Salpus used his subclan seniority to influence profit distribution; and, the operators of Patrick's store were eventually unable to contain dissent between coinvestors. The "failure" of Patrick's store parallels the fissioning of lineages that occurs each generation or two. Patrilineally-held resources such as sago and coffee holdings, for example, are often subdivided each generation between adult brothers. Similarly, tradestores as resources are under the same pressure for sub-division, but there are additional stresses related to their role as vehicles for deriving prestige and political standing (see below). Patrick's store held together successfully for a decade until the store operators were unable to keep the lid on pressures to fission -pressures due in large part to the emergence of a new generation of aspiring leaders seeking to forge their own political, social and economic identity.

Raising capital and profit distribution should not be viewed solely as market transactions in which there are no other considerations apart from an anticipated return on the initial investment. Principles rooted in the indigenous exchange economy are clearly at work. Investment returns bear little relationship with initial investment level and kinship again appears to play a significant role. While the data are inconclusive, they are suggestive of a more standard rate of return for more distantly related agnatic investors, whereas return rates for more closely related agnates appear to be negotiable, perhaps subject to the myriad contingencies of intrapatrilineage and subclan debt obligations. Within the subclan, for example, one would anticipate that returns are affected by existing obligations and debts, not only by subclan members acquiring stock on credit, but by the set of debts in the indigenous exchange economy arising, say, through past contributions to brideprices.

While some tradestore operators are able to raise their own capital to establish a store most are group investments. The set of kin drawn upon for start-up capital is similar to the range of kin and social networks used to support large indigenous exchange transactions such as brideprices, mortuary and compensation payments and the staging of ritual events. For example, the groom's father and other close agnates contribute a large share of the brideprice while more distantly related agnates from the subclan and clan may contribute only token amounts to acknowledge agnatic ties. Tradestore investments appear to follow this pattern with close agnates contributing more capital than more distantly related agnates. Next to the groom's father the second largest brideprice contributor is the groom's mother's brother. The act of investment in sister's son's marriage is an exchange that reinforces the kinship tie between them, and marks an enduring social and economic relationship that often persists into the next generation. Similarly, tradestore investments by affines seem to be a recurring feature in the Wosera, and Beno, one of the largest investors in Case 3, declined an investment return citing the culturally-defined role of mother's brother in nurturing and supporting his sisters' children.

Therefore, group investments in tradestores should not be viewed as the inability of store operators to raise sufficient capital themselves. Rather, the activation of social and kinship networks to bring a tradestore into existence is an act infused with notions of group identity and the formation/reinforcement of social relationships. There are 
two aspects to this. First, bisnis investments share many similarities with indigenous exchange transactions as discussed above. In PNG, as in most of Melanesia, indigenous exchange is central to individual and group social identity. Exchange is what makes relationships: allegiances are formed, relative status is determined and group boundaries are given definition. It is in this way that the role of tradestore investments becomes difficult to disentangle from that of indigenous exchange; not only are co-investors drawn from the same social groups and range of kin, but the meanings that they attach to their investment acts are not dissimilar to those they attach to more clearly defined indigenous exchange transactions such as brideprice contributions. Thus tradestore investments help define groups and are relationshipforming in ways that are additional to, or qualitatively different from, more strictly defined market transactions.

The second related aspect of pooled investments is in the way they mobilise groups for projects of various kinds. It has long been recognised in PNG, that male status and social standing often reflect men's ability to mobilise large groups for communal projects, traditionally in the realm of kastam, but now also in bisnis. Men able to mobilise large social networks for the pooling of labour and cash to found tradestores achieve status and renown. The ability to convert a collective effort into a large, preferably "modern" tradestore benefits themselves and members of shared networks. Their ability to do so depends both on the success of their tradestores as businesses and on their skills as aspiring bigmen to maintain and strengthen their support bases within their local communities.

This raises the question of whether the customer base of a store is dependent on the status of the store operator. ${ }^{16}$ Put differently, are bigmen, or men on their way to becoming bigmen, able to convert networks of support into increased patronage of their stores? While the question is beyond the scope of this paper, it does seem likely because of the close similarities in the ways in which tradestores and events/activities in the realm of kastam are managed and valued by society. Bigmen have more extensive networks of supporters which can be drawn upon for large exchange transactions or the staging of large-scale ceremonial events. Similarly, such individuals would be anticipated to draw upon such networks to establish a store or other bisnis enterprise, and it is probable that such networks would translate into an enlarged customer base. My observations of tradestores throughout the Wosera would suggest that this is indeed the case. Large tradestores are often managed by prominent individuals with reputations that extend well beyond the village boundary - many have political connections and hold official positions, and many serve as spokesmen/representatives for their communities.

While the act of mobilising large groups for various projects generates prestige and social status for the chief organiser and his followers, such acts can also result in enduring physical evidence of this success in the form of, for example, trucks and tradestores. Tradestores provide visible evidence of the ability of store operators to recruit followers and investors to pool wealth and labour -- the hallmark skills of the traditional bigman. Moreover, tradestore structures are physical expressions of modernity in the heart of the village immediately recognisable to all, and, like tinned fish and rice, carry significant prestige because of their association with the modern world. The social capital they generate in the form of prestige and status is in direct 
proportion to the degree that store operators and their supporters are able to reproduce physically the symbols of the modern market economy. Thus a corrugated iron store with concrete flooring is more prestigious than a timber store which in turn has more prestige than one made from bush materials. Tradestores therefore provide physical evidence of an individual and group's success in both bisnis AND kastam.

Perhaps this is best illustrated by the paradox that tradestores do not have to be in "business" to be successful; the insolvent village tradestore closed indefinitely remains a source of prestige for the operator and his followers, though less so than a functioning well-stocked store. Goddard (1995), amongst others, draws attention to this point when he notes many development projects in PNG collapse after promising beginnings. Projects and enterprises established for the ostensible purpose of profit accumulation in accordance with western notions of development may be driven largely by indigenous rather than market considerations. Moreover, as Goddard points out, if they are built primarily as material symbols of "progress", then they may not develop much beyond an embryonic stage. The concept of prestige is useful here because it highlights the differences in perceptions between developers and the people with whom they work. It suggests that much of what western development experts understand development to mean can be wildly divergent from the views of people in whose interests they putatively serve. As Goddard (1995: 67-69) notes:

their [development projects] acquisition is often influenced by complexities of prestige and obligation that are rarely anticipated by development planners. ... Development projects, especially those with community input, whether they be small business or infrastructure, become enmeshed in local variants of the general gift economy whose permutations are impenetrable from the point of view of "economic growth."

Similarly, the Wosera tradestore is functionally and symbolically an articulation of the two forms of socio-economy, where values, relations and behaviours associated with each framework are drawn upon in complex ways to create a hybrid phenomenon. Such hybrid enterprises are now a durable part of the cultural and economic landscape of rural PNG.

\section{Conclusion}

The apparent embrace of the market economy reflected in villagers' enthusiasm for business like tradestores, belies the significance of the indigenous socio-economy in shaping how tradestores are established, operated, patronised and valued in Wosera society. On this evidence it would be difficult to maintain that tradestores are indicative of a transition to a market economy where market relations are displacing indigenous economic and social relations. Nor can we be confident that market relations are undermining "traditional" interests, values and economic structures. Instead, what appears to the external observer a modern market phenomenon is, in reality, imbued with indigenous values and meanings that are pre-modern and nonmarket in form. 
The evidence suggests that Wosera tradestores do not occupy a realm distinct and separate from the rest of Wosera life, in which indigenous socio-economic forms, values and behaviours are suspended so that market economic relations prevail. Although tradestores represent a partial commercialisation of social relationships and are a way to raise capital, the economic and socio-cultural dimensions of their operations are, as the new economic geography reveals for modern economies, 'incorrigibly intertwined, unable to be separated off from one another' (Thrift and Olds, 1996: 314). However, the form of their embeddedness differs in a fundamental way from the forms of social embeddedness of modern economies discussed in the literature of the new economic geography. While Taiwanese investors in southern China practice gift exchange with their local business partners to develop trusting interpersonal relationships, the development of these relationships is ultimately about facilitating capital investments and generating profits. In the Melanesian context this is not always the case as this paper reveals for Wosera tradestores. While most Wosera tradestores straddle both the market and indigenous economies simultaneously, market imperatives are often subordinated to the needs of the social and cultural so that, for example, tradestores can become vehicles primarily for facilitating gift exchange rather than generating profits.

Recognition of the social and cultural dimensions of these emergent market forms has implications for how development is viewed and practised. As indicated in the introduction to this paper, there is now increasing recognition of the resilience of precapitalist structures and values and that the direction of change is uncertain and dynamic, giving rise to a plurality of socio-economic forms at the local level which often diverge from idealised market forms. Introduced and indigenous economic forms and values are being blended to create almost hybrid socio-economies, to the extent that conceptual dualisms like "market" and "non-market", "modern" and "traditional", and "capitalist" and "precapitalist" are breaking down and losing their usefulness. Consequently, conventional functionalist and structuralist perspectives are increasingly being challenged for their deterministic and universalistic interpretations of change and because their reference point for change is the now industrialised world, so that, for example, western concepts of rationality are emphasised (e.g., Edwards, 1989; Nederveen Pieterse, 1994; Mehmet, 1995; Escobar, 1995).

Such Eurocentric perspectives deny alternative views of development apart from the idealised western one defined according to western values and concepts, particularly the market economy with its emphasis on individual self-interest. While the new economic geography has effectively critiqued such perspectives with respect to modern economies by revealing the social embeddedness of economic life, in the socalled developing world, departures from this ideal market type are still viewed by many aid donors as aberrations or, worse, development failures. From the perspective of neo-classical economics, for example, the "under-performing" village tradestore is labelled "inefficient" or a market "failure" with the cause attributed to deficiencies in the objects of development -- rural villagers. Rural people come to be viewed as barriers to development. As Escobar (1995) would argue, they become categorised as "uneducated", "irrational", "superstitious" and so on, objects to be processed by the development industry, despite the profit motive not being the sole or even primary motivation. 
Thus, the alternative perspective that the new economic geography brings to the study of modern economies is also relevant and useful for the study of emerging economic forms in the developing world. For human geographers working in this field, the new economic geography is less Eurocentric and deterministic than some earlier approaches and has a healthy respect for local agency. Also, because it emphasises the social and cultural dimensions of economic life, it has the potential to provide valuable insights into processes of socio-economic change, particularly indigenous social and cultural meanings of "development". Thus, it could become an effective tool with which to critique some of the more Eurocentric and market-dominated assumptions underpinning much of current aid practice.

Acknowledgements--I wish to thank Gina Koczberski and Drs Robin Hide and Andrew Leyshon for their valuable comments on an earlier version of this paper. I also received useful feedback at seminar presentations of aspects of this paper from colleagues in the Department of Human Geography, Research School of Pacific and Asian Studies, Australian National University and in the School of Social Sciences, Curtin University of Technology. The helpful comments of three anonymous referees are also gratefully acknowledged. Finally, I am indebted to many people for assistance and hospitality during fieldwork, especially villagers from the Wosera subdistrict who generously gave their time and assistance.

\section{Notes}

1. Nederveen Pieterse's (1994) work on hybridisation and Simon's (1997; 1998) concept of postraditionalism are relevant here. See Koczberski and Curry (forthcoming) for an example of how posttraditionalism has been been applied to indigenous concepts of health and illness in PNG.

2. The term 'bigman' is thought to have been coined by Mead in 1935 (Lindstrom, 1981 cited in Feil, 1987, 96). Sahlins (1963) used the term to describe Melanesian societies where leadership is achieved rather than ascribed, and to distinguish them from Polynesian chiefly societies of inherited rank. Males become bigmen in competition with one another in various fields such as oratory, warfare, magic, ritual and horticulture. Most important, however, is that they excel in ceremonial exchange by accumulating and strategically redistributing wealth. From this system of competitive exchange bigmen emerge from a mass of economically undifferentiated ordinary men. Males, if successful in competition with other males, become bigmen and accrue advantages from such status including political power, wealth, and more wives (labour) than ordinary men. The bigman system is not ubiquitous in PNG and there are deviations from the classic type as envisaged by Sahlins (for further discussion see Godelier, 1982; Feil, 1987; Lederman, 1990; Lepowsky, 1990). 3. PNG gift exchange is explicitly about the development of personal and group relationships and is grounded in clan-based systems of social organisation.

4. The embeddedness of money in social relations in market economies is receiving increasing attention (e.g., Dodd, 1994; Zelizer, 1994; Thorne, 1996). This is undermining conventional views of monetisation as a process of homogenisation and flattening of social relations (Zelizer, 1994; for a brief overview see Leyshon, 1997). 
5. The Melanesian pidgin terms bisnis and kastam do not coincide exactly in meaning with the English words business and custom. Bisnis, while encompassing what is conventionally meant by business, has a broader meaning and can include activities that have non-market elements such as 'singsing bisnis'.

6. Not all the recent anthropological research on this topic in PNG finds an ambiguous boundary between indigenous and market economic forms. For instance, Foster (1992; also 1995) reports a rigid functional divide between the two socioeconomies in the Tanga Islands, New Ireland Province.

7. This unusually low figure is attributable to the collapse of coffee prices in 1989. Efforts to expand garden production (e.g., peanuts) for sale at local markets were probably insufficient to compensate fully for the loss of coffee income.

8. Despite fluctuating prices, coffee and more recently cocoa have become important export cash crops throughout the sub-district.

9. In addition to the items listed in Figure 2, large tradestores may carry tinned meat, soft drinks, powdered milk, tea, sugar, navy biscuits, kerosene lamps, clothing, sewing materials, bleach, tobacco products, torches, fishing lines and hooks, catapult rubber, cigarette lighters and bush knives. Some also act as coffee buyers.

10. Large store operators often have extensive business connections and crossinvestments in transport businesses like a truck, and, therefore, receive a freight subsidy on supplies of stock.

11. Locally marketed smoked fish from the Sepik River is a less prestigious food item than imported tinned fish. The former retails at $43 \%$ less a kilo than tinned fish, but the latter is much preferred in terms of quantities purchased. There does not seem to be a marked seasonality to the consumption of tinned fish, but supplies of smoked fish can diminish during seasonal flooding of the Sepik River. While very poor villagers rarely purchase tinned fish because of a lack of cash, they are able to obtain smoked fish by bartering garden produce. Villagers who buy tinned fish regularly, do not seem to reduce their purchases when local fish is available. Rather they tend to consume more fish in total.

12. The remaining $9 \%$ of expenditure in the market economy is on public transport. Items on sale at local markets commonly include garden produce, peanuts, processed foods like raw sago, sago and banana pudding and boiled corn, locally grown tobacco, betel nut and lime, and, smoked fish from the Sepik River.

13. Continual expenses on vehicle repairs drained the store of profits and operating funds, and eventually it became insolvent.

14. K50 was given to Bert in recognition of his initial investment in the store and K50 to Jack because he often helped at the store when Puse was absent.

15. In the three years to 1982 no profits were formally distributed, but it is likely that slow profit growth was indicative of Bill and some of his co-investors consuming stock themselves and/or investing stock in indigenous exchange.

16. The study did not examine large Wosera tradestores. These store operators were often bigmen or aspiring bigmen with political connections and large networks of supporters.

\section{References}

Amin, A. and Thrift, N. (1992) Neo-Marshallian nodes in global networks. International Journal of Urban and Regional Research 16, 571-87. 
Amin, A. and Thrift, N. (1995) Institutional issues for the European regions: from markets and plans to socioeconomics and powers of association. Economy and Society 24, 41-66.

AusAID (1995) Papua New Guinea: Improving the Investment Climate. International Development Issues No. 39. Anutech Pty Ltd, Canberra.

Berry, B.J.L. (1967) Geography of Market Centers and Retail Distribution. Prentice Hall, Englewood Cliffs.

Boyd, D.J. (1985) The commercialisation of ritual in the Eastern Highlands of Papua New Guinea. Man 20, 325-340.

Brookfield, H.C. (ed.) (1973) The Pacific in Transition. Edward Arnold, London.

Carrier, J.G. (1992) The gift in theory and practice in Melanesia: a note on the centrality of gift exchange. Ethnology 31, 185-193.

Carrier, J.G. (1995) Maussian occidentalism: gift and commodity systems. In Occidentalism. Images of the West, ed J. G. Carrier. pp. 85-108. Oxford University Press, Oxford.

Carrier, J.G. (ed.) (1997) Meanings of the Market. The Free Market in Western Culture. Berg, Oxford.

Carrier, J.G. and Carrier, A.H. (1989) Wage, Trade, and Exchange in Melanesia. A Manus Society in the Modern State. University of California Press, Berkeley.

Clark, J.L. (1989) The incredible shrinking men: male ideology and development in a southern highlands society. Canberra Anthropology 12(1 and 2), 120-143. Special Volume - Culture and Development in Papua New Guinea.

Connell, J. (1997) Papua New Guinea: The Struggle for Development. Routledge, London.

Curry, G. (1992) Kin and Kina: A Study of Emerging Inequalities in a Rural Lowland Society in Papua New Guinea. Unpublished PhD thesis, University of New England.

Curry, G. (1997) Warfare, social organisation and resource access amongst the Wosera Abelam of Papua New Guinea. Oceania 67(3), 194-217.

Curry, G. and Koczberski, G. (1998) Migration and circulation as a way of life for the Wosera Abelam of Papua New Guinea. Asia Pacific Viewpoint 39(1), 2952.

Curry, G. and Koczberski, G. (in press) The risks and uncertainties of migration: an exploration of recent trends amongst the Wosera Abelam of Papua New Guinea. Oceania.

Dodd, N. (1994) The Sociology of Money: Economics, Reason and Contemporary Society. Polity Press, Cambridge.

Edwards, M. (1989) The irrelevance of development studies. Third World Quarterly 11, 116-135.

Escobar, A. (1995) Encountering Development: The Making and Unmaking of the Third World. Princeton University Press, New Jersey.

Feil, D.K. (1987) The Evolution of Highland Papua New Guinea Societies. Cambridge University Press, Cambridge.

Finney, B.R. (1973) Big Men and Business: Entrepreneurialship and Economic Growth in the New Guinea Highlands. University of Hawaii, Hawaii.

Foster, R.J. (1992) Commoditization and the emergence of kastam as a cultural category: a New Ireland case in comparative perspective. Oceania 62, 284-294. 
Foster, R.J. (1995) Social Reproduction and History in Melanesia: Mortuary Ritual, Gift Exchange, and Custom in the Tanga Islands. Cambridge University Press, New York.

Goddard, M. (1995) The rascal road: crime, prestige and development in Papua New Guinea. The Contemporary Pacific 7(1), 55-80.

Godelier, M. (1982) Social hierarchies among the Baruya of New Guinea. In Inequality in New Guinea Highlands Societies, ed A. Strathern. pp. 3-34. Cambridge University Press, Cambridge.

Granovetter, M. (1985) Economic action and social structure: the problem of embeddedness. American Journal of Sociology 91, 481-510.

Gregory, C.A. (1980) Gifts to men and gifts to God: gift exchange and capital accumulation in contemporary Papua. Man 15(4), 626-652.

Gregory, C.A. (1982) Gifts and Commodities. Academic Press, London.

Gregory, C.A. (1997) Savage Money: the Anthropology and Politics of Commodity Exchange. Harwood Academic Publishers, Amsterdam.

Grossman, L.S. (1986) Consumer behavior and the village tradestore: a Papua New Guinea example. Geografiska Annaler 68(B), 41-49.

Heywood, P., Allen, B., Fandim, T., Garner, P., Hide, R., Joughin, J., Junembarry, J., Mathie, A., Numbuk, S., Ross, J. and Yaman, C., (1986) A Rapid Rural Appraisal of Agriculture, Nutrition and Health in the Wosera Sub-district, East Sepik Province. Papua New Guinea Institute of Medical Research, Madang.

Howlett, D. (1973) Terminal development: from tribalism to peasantry. In The Pacific in Transition, ed H. Brookfield. pp 249-273. Edward Arnold, London.

Hsing, Y. (1996) Blood, thicker than water: interpersonal relations and Taiwanese investment in southern China. Environment and Planning A 28, 2241-2261.

Koczberski, G. and Curry, G. (in press) Sik bilong ples: an exploration of meanings of illness and well-being amongst the Wosera Abelam of Papua New Guinea. Australian Geographical Studies.

Lea, D., Joel, N. and Curry, G. (1988) A Maprik journey: backwards or forwards in time? Cash cropping among the Abelam. In Small-Scale Agriculture, eds J. Hirst, J. Overton, B. Allen and Y. Byron, pp. 23-31. Commonwealth Geographical Bureau and ANU Department of Human Geography, Canberra.

Lederman, R. (1990) Big men, large and small? towards a comparative perspective. Ethnology 24, 3-15.

Lepowsky, M. (1990) Big men, big women, and cultural autonomy. Ethnology 24, 35-50.

Leyshon, A. (1997) Geographies of money and finance II. Progress in Human Geography 21, 381-392.

Leyshon, A., Thrift, N. and Pratt, J. (1998) Reading financial services: texts, consumers, and financial literacy. Environment and Planning D: Society and Space 16, 29-55.

Light, I. and Karageorgis, S. (1994) The ethnic economy. In The Handbook of Economic Sociology, eds N. J. Smelser and R. Swedberg. pp 647-71. Princeton University Press and Russell Sage Foundation, Princeton and New York.

Lindstrom, L. (1981) Big-man: a short terminological history. American Anthropologist 83, 900-905.

Maclean, N.A. (1989) The commoditization of food: an analysis of a Maring market. Canberra Anthropology 12(1 and 2), 74-98. Special Volume - Culture and Development in Papua New Guinea. 
Mehmet, O. (1995) Westernizing the Third World: the Eurocentricity of Economic Development Theories. Routledge, London.

Misztal, B. A. (1996) Trust in Modern Societies: The Search for the Bases of Social Order. Polity Press, Cambridge.

Nederveen Pieterse, J.N. (1994) Globalisation as hybridisation. International Sociology 9(2), 161-184.

Nihill, M. (1989) The new pearlshell: aspects of money and meaning in Anganen exchange. Canberra Anthropology 12(1 and 2), 144-161. Special Volume Culture and Development in Papua New Guinea.

Platteau, J. (1994a) Behind the market stage where real societies exist. Part I: the role of public and private order institutions. The Journal of Development Studies 30, 533-577.

Platteau, J. (1994b) Behind the market stage where real societies exist. Part II: the role of moral norms. The Journal of Development Studies 30, 753-817.

Polanyi, K. (1957) The Great Transformation: The Political and Economic Origin of Our Times. Beacon Press, Boston.

Sahlins, M. (1963) Poor man, rich man, big man, chief: political types in Melanesia and Polynesia. Comparative Studies in Society and History 5, 285-300.

Simon, D. (1997) Development reconsidered: new directions in development thinking. Geografiska Annaler Series B, Human Geography 79B, 183-201.

Simon, D. (1998) Rethinking (post)modernism, postcolonialism, and posttraditionalism - South-North perspectives. Environment and Planning D Society and Space 16, 219-245.

Smart, J. and Smart, A. (1991) Personal relations and divergent economies: a case study of Hong Kong investment in south China. International Journal of Urban and Regional Research 15, 216-233.

Strathern, A.J. (1974) Anthropology and problems of social change in Papua New Guinea. Inaugural lecture, University of Papua New Guinea.

Swedberg, R. (1994) Markets as social structures. In The Handbook of Economic Sociology, eds N. J. Smelser and R. Swedberg. pp 255-82. Princeton University Press and Russell Sage Foundation, Princeton and New York.

Thorne, L. (1996) Local exchange trading systems in the United Kingdom: a case of re-embedding? Environment and Planning A 28, 1361-1376.

Thrift, N. (1994). On the social and cultural determinants of international financial centres: the case of the City of London. In Money, Power and Space, eds S. Corbridge, N. Thrift, and R. Martin. pp 327-355. Blackwell, Oxford.

Thrift, N. (1996) Spatial Formations. Sage, London.

Thrift, N. and Olds, K. (1996) Refiguring the economic in economic geography. Progress in Human Geography 20, 311-337.

Williams, N.J. (1979) The definition of shopper types as an aid in the analysis of spatial consumer behavior. Tijdschrift voor Economische en Sociale Geografie 70, 157-163.

Yeung, W.C.H. (1994) Critical reviews of geographical perspectives on business organisations and the organisation of production: towards a new network approach. Progress in Human Geography 18, 40-490.

Zelizer, V. (1994) The Social Meaning of Money. Basic Books, New York.

Zimmer-Tamakoshi, L. (1997) The last big man: development and men's discontents in the Papua New Guinea highlands. Oceania 68, 107-122. 
Zucker, L. (1986) Production of trust: institutional sources of economic structure. Research in Organisational Behaviour 8, 53-111.

Figure 1. Location of study site.

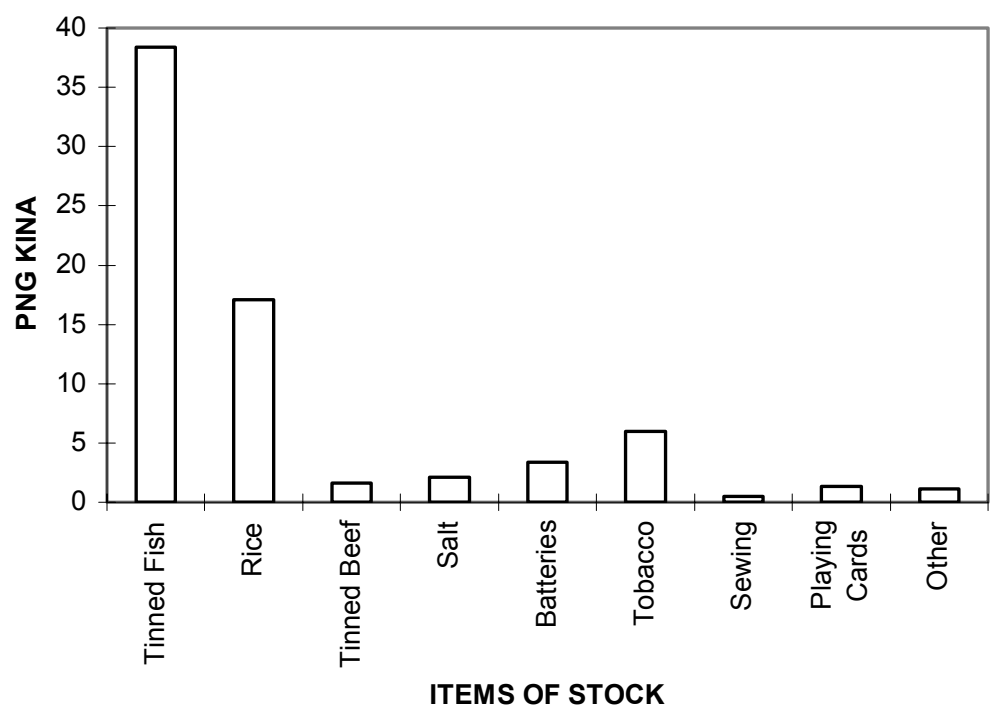

Figure 2. Average monthly stock purchases of a typical Wosera tradestore between March 1986 and July 1988 (calculated from wholesale receipts held by store operator).

Table 1. Mean household weekly expenditure on tradestore goods and number of weeks per year in which at least one tradestore transaction was made $(n=31)$.

\begin{tabular}{lll}
\hline & $\begin{array}{l}\text { Expenditure per week } \\
\text { (Kina) }\end{array}$ & Purchases (weeks per year) \\
\hline Mean & 1.7 & 36.2 \\
s.d. & 1.0 & 11.1 \\
Min & 0.3 & 11.8 \\
Max & 4.2 & 52 \\
\hline
\end{tabular}


Table 2. Tradestore expenditure by location averaged for 31 households: (A) per cent of total tradestore expenditure over entire survey period; (B) tradestore expenditure per week for weeks in which a tradestore purchase occurred; (C) expenditure on each item during a transaction at a tradestore.

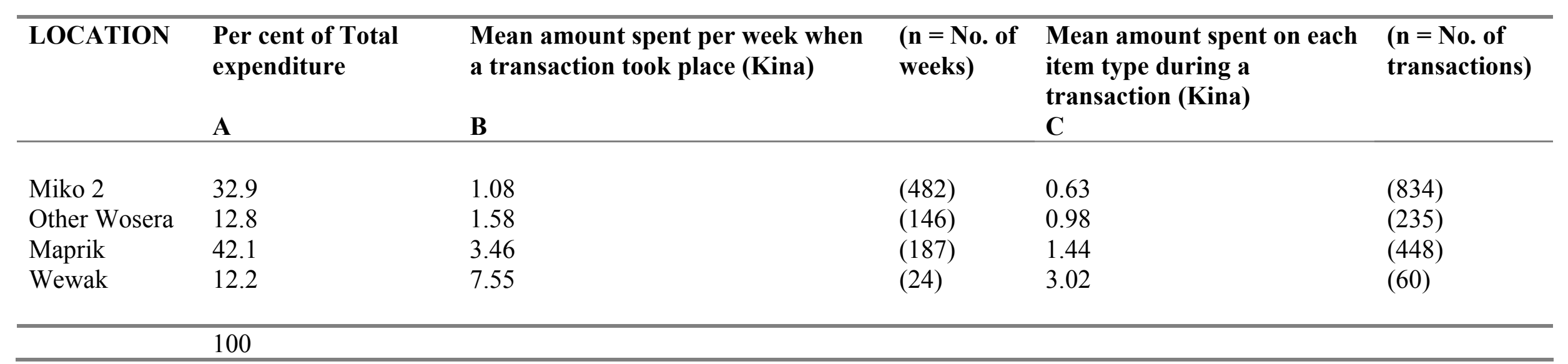


Table 3. Per cent of tradestore expenditure at nearest store to residence and store operated by a subclan member.

\begin{tabular}{lll}
\hline & $\begin{array}{l}\text { Nearest store to hamlet } \\
(\mathrm{n}=34)\end{array}$ & Subclan store $(\mathrm{n}=25)$ \\
\hline Mean & 29.8 & 42.9 \\
S.d. & 26.8 & 30 \\
Min & 0 & 0 \\
Max & 91 & 100 \\
\hline
\end{tabular}

Table 4. Capital invested and profit distribution by kinship relationship

\begin{tabular}{llll}
\hline & $\begin{array}{l}\text { Relationship } \\
\text { to Puse }\end{array}$ & $\begin{array}{l}\text { Investment } \\
\text { (PNG Kina) }\end{array}$ & $\begin{array}{l}\text { Investment Returns } \\
\text { (PNG Kina) }\end{array}$ \\
\hline Puse & Mother's brother & 100 & $700^{*}$ \\
Joe & Mother's brother & 100 & 200 \\
Joe's son & Mother's brother & 100 & 200 \\
Joe's son & Subclan & 60 & 200 \\
Salpus & Mother's brother & 20 & 300 \\
Bert & Mother's brother & 20 & nil** \\
Thomas & Sister's son & 10 & $20^{* * *}$ \\
Jack & Subclan & 10 & nil** \\
Alice & Subclan & 10 & nil \\
Ben & & $\mathbf{4 4 0}$ & nil \\
TOTALS & & $\mathbf{1 , 6 2 0}$ \\
\hline
\end{tabular}

* $\quad$ Salpus has claimed this investment for himself - see text.

** $\quad$ Bert and Jack received K50 each from Joe after the profit distribution - see text.

*** Thomas received an additional K50 worth of store foods when he organised a string band competition. 